\title{
MODIFICATION OF PURUN TIKUS (ELEOCHARIS DULCIS) AS A NATURAL FIBER COMPOSITE USING $\mathrm{KMnO}_{4}$ AND NaOH
}

\author{
Ninis Hadi Haryanti ${ }^{1}{ }^{1 *}$, Suryajaya ${ }^{1}$, Lies Banowati ${ }^{2}$, Mawaddatur Rahmah ${ }^{1}$, \\ Akhmad Safi' ${ }^{1}$

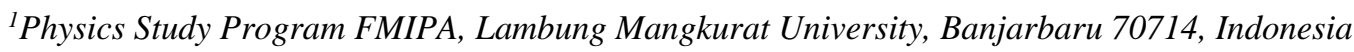 \\ ${ }^{2}$ Nurtanio University, Bandung, Indonesia \\ *Corresponding Author Email: ninishadiharyanti@ulm.ac.id
}

Received: 27 November 2020 Revised: 10 March 2021

Accepted: 7 April 2021

Online: 29 April 2021

Published: 30 April 2021

SPEKTRA: Jurnal Fisika dan Aplikasinya p-ISSN: 2541-3384

e-ISSN: 2541-3392

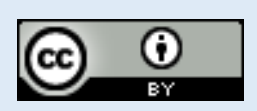

\begin{abstract}
The choice of natural fibers as a composite reinforcing material is related to the advantages of being cheap, abundant, renewable, and environmentally friendly. This research was conducted to study the effect of de-lignification treatment on the properties of purun tikus (Eleocharis Dulcis) fiber. Purun tikus fiber has been modified with the alkaline treatment of $\mathrm{KMnO}_{4} 2 \%$ and $\mathrm{NaOH} 5 \%$. This treatment was mainly applied to improve the physical and chemical properties of purun tikus fiber. Changes in chemical characteristics (water, lignin, cellulose, and hemicellulose), physical (density), mechanical (tensile strength), morphology, and elemental content of purun tikus before and after treated with alkaline were studied. The measurements showed an increase in water content and density while lignin, cellulose, and hemicellulose were decreased. Thus the alkaline treatment of $\mathrm{KMnO}_{4} 2 \%$ and $\mathrm{NaOH} 5 \%$ reduced lignin, cellulose, and hemicellulose of the purun tikus fiber to reduce the size of the fibers, as shown in SEM measurements. There was a change in elemental content after being treated with $\mathrm{KMnO}_{4} 2 \%$ and $\mathrm{NaOH} 5 \%$. NaOH treatment was better than $\mathrm{KMnO}_{4}$ treatment in terms of removing lignin and hemicellulose in purun tikus fiber. Although the tensile strength of the purun fibers treated with $\mathrm{KMnO}_{4} 2 \%$ and $\mathrm{NaOH} 5 \%$ were lower than untreated, with less lignin, cellulose, and hemicellulose, it is expected that these fibers will blend better in the composite and improved its mechanical properties.
\end{abstract}

Keywords: purun tikus fiber, chemical properties, physical properties, mechanical properties, composite materials 


\section{INTRODUCTION}

Composite material combines two or more materials to form a microscopic unit, which is made of various combinations of properties or a combination of binding material and reinforcing material [1]. Fibers were normally used as reinforcement in composite material. As reinforcement, fibers determine the properties of the resulting composite by distributing the load into the matrix. Nowadays, industries tend to use natural fibers, which are more environmentally friendly because they are naturally degraded, and the price of natural fibers is lower than synthetic fibers. Besides that, natural fibers have a low density, biodegradable, recycle easily, require low energy in production, have good mechanical properties, and renewable [2]. In addition, natural fibers are candidates as reinforcing materials to produce composite materials that are lightweight, strong, environmentally friendly, and economical [3]. Natural fiber needs tend to increase in line with the increasing demand for environmentally friendly materials.

In terms of natural fiber availability, South Kalimantan Province has plenty. One of them is purun tikus (Eleocharis dulcis) which is a wild plant in swamp areas. The rapid growth of purun tikus causes it to be categorized as a weed. Until now, purun tikus has been used for handicrafts and swam buffalo food [4]. Several studies have used purun tikus as a biofilter [5], a heavy metal absorber [4], cement board composite material [3,4], and activated charcoal [8]. In a previous study, purun tikus have a structure consisting of lignin, hemicellulose, and cellulose, and expected could be used as natural fibers [9]. The cellulose in purun tikus is the reinforcing material, while lignin and hemicellulose provide stiffness and protection against fibers. Before being used as a natural fiber, purun tikus needs to be treated using an alkaline solution to reduce unused fiber elements such as hemicellulose, lignin, pectin, and other elements so that only cellulose remains in the fiber. The alkaline treatment is expected to be able to remove the content that binds cellulose in purun tikus fibers. The purpose of the treatment process is to break down the lignin structure, break down cellulose crystals, increase the porosity of the material, break down hemicellulose, and depolymerize hemicellulose. Given the alkaline treatment can also reduce the size of the fiber which in turn will expand the contact between surfaces and can improve mechanical properties.

Several studies have stated that there is an effect of using $\mathrm{KMnO}_{4}$ and $\mathrm{NaOH}$ solutions on natural fibers [9-11]. $\mathrm{KMnO}_{4}$ is an inorganic compound and is often used as a strong oxidizing agent. Likewise, $\mathrm{NaOH}$ is classified as a strong base that can be used for cellulose extraction. The results obtained showed a significant and effective change in the alkaline treatment of natural fibers with various concentrations. Differences in concentrate and immersing time have been applied to different natural fibers. The goal is to produce optimal mechanical properties. In several studies, the highest chemical, physical and mechanical properties were shown at the concentration of $\mathrm{NaOH} 5 \%$ and $\mathrm{KMnO}_{4} 2 \%$ [4,9-11].

The use of purun tikus as reinforcing material in composite materials is expected to replace the use of synthetic reinforcing materials. Before they could be used as composite materials, the chemical, physical, and mechanical properties of purun tikus fibers as well as their morphology and elemental content, needed to be known. Therefore, in this study, the 
characteristics (chemical, physical, mechanical) of purun tikus fiber would be determined as well as its morphology and elemental content before and after being treated with $\mathrm{KMnO}_{4} 2 \%$ and $\mathrm{NaOH} 5 \%$ for 3 hours.

\section{RESEARCH METHODS}

Purun tikus with a length of 100-160 cm were cleaned and dried by drying in the sun for $2 \mathrm{x}$ 8 hours then stored for at least three months. To make fiber, purun tikus was cut into pieces with a maximum length of $2 \mathrm{~cm}$, then blending it into thin shavings. Then purun tikus fibers were washed with water accompanied by stirring and heating at $80^{\circ} \mathrm{C}$ for 1 hour, then washed with cold water. After that, the fibers were delignified using $\mathrm{KMnO}_{4} 2 \%$ or $\mathrm{NaOH} 5 \%$ at the same temperature, accompanied by stirring at a rotational speed of $250 \mathrm{rpm}$ for 3 hours. The measurement of water, lignin, cellulose, hemicellulose, tensile strength, and density, and morphology were carried out on three types of samples: without treatment, treatment with $\mathrm{KMnO}_{4} \%$, and treatment with $\mathrm{NaOH} 5 \%$.

Water content was needed to determine the feasibility of purun tikus fiber as a composite material by referring to the SNI 06-3730-1995 standard. According to these standards, the maximum water content is about $15 \%$ [13]. Calculation of the percentage of water content in purun tikus is:

Water content $(\%)=\frac{(A-B)}{C} \times 100 \%$

where $\mathrm{A}=$ Weight (sample + plate) before drying, $\mathrm{B}=$ Weight (sample + plate) after drying, $\mathrm{C}=$ Weight of sample.

The lignin content was carried out based on SNI 0492-1989-A [14]. Calculation of the percentage of lignin in purun tikus fiber is:

Lignin $(\%)=\frac{\text { lignin sediment weight }}{\text { dry sample weight }} \times 100 \%$

The cellulose content was carried out based on SNI 14-0444-1989. The cellulose content, according to SNI 14-0444-1989 standards, is more than 80\% [15]. Calculation of the percentage of cellulose in purun tikus fiber is:

Cellulose $(\%)=\frac{\text { cellulose sediment weight }}{\text { dry material weight }} \times 100 \%$

The hemicellulose content was carried out based on SNI 14-0444-1989 [15]. Calculation of the percentage of hemicellulose in purun tikus fiber:

Hemicellulose $(\%)=\frac{\left(V_{2}-V_{1}\right) \times N \times 6,85}{W}$

where: $\mathrm{V} 1=$ requirement of $\mathrm{Na}_{2} \mathrm{~S}_{2} \mathrm{O}_{3}$ in the filtrate titration, $\mathrm{V} 2=$ requirement of $\mathrm{Na}_{2} \mathrm{~S}_{2} \mathrm{O}_{3}$ in the titration blanko, $\mathrm{N}=$ normality of $\mathrm{Na}_{2} \mathrm{~S}_{2} \mathrm{O}_{3}, \mathrm{~W}=$ weight of dry matter that has been oven (gram), $6.85=\mathrm{mg}$ of cellulose is equivalent to 1 milliequivalent of $\mathrm{K}_{2} \mathrm{Cr}_{2} \mathrm{O}_{7}$.

The density of purun tikus fiber was carried out by weighing the mass of purun tikus \pm 2 grams in each of 3 samples of purun tikus. The sample of purun tikus was then put into the water and the increase in water volume was measured. The calculation of the density of the purun tikus is carried out through a comparison according to the following equation: 
$\rho=\frac{M}{V}$

where $\mathrm{M}=$ mass of fiber, $\mathrm{V}=$ volume.

The fiber tensile strength test was carried out using one-third of purun tikus fiber with length of $40 \mathrm{~cm}$. The stages of the analysis of the purun tikus tensile test were based on ASTM D3379-75 [15]. Meanwhile, the morphology and the elemental content of the purun tikus fiber was yielded from SEM-EDX measurement.

\section{RESULTS AND DISCUSSION}

The SEM-EDX measurement was carried out to determine the details of the sample in a highresolution image and identifying the elements present in the sample. The results of SEM-EDX of purun tikus fiber for 3 types of samples (without treatment, treated with $\mathrm{KMnO} 42 \%$, and treated with $\mathrm{NaOH}$ 5\%) are shown in FIGURE 1 below.
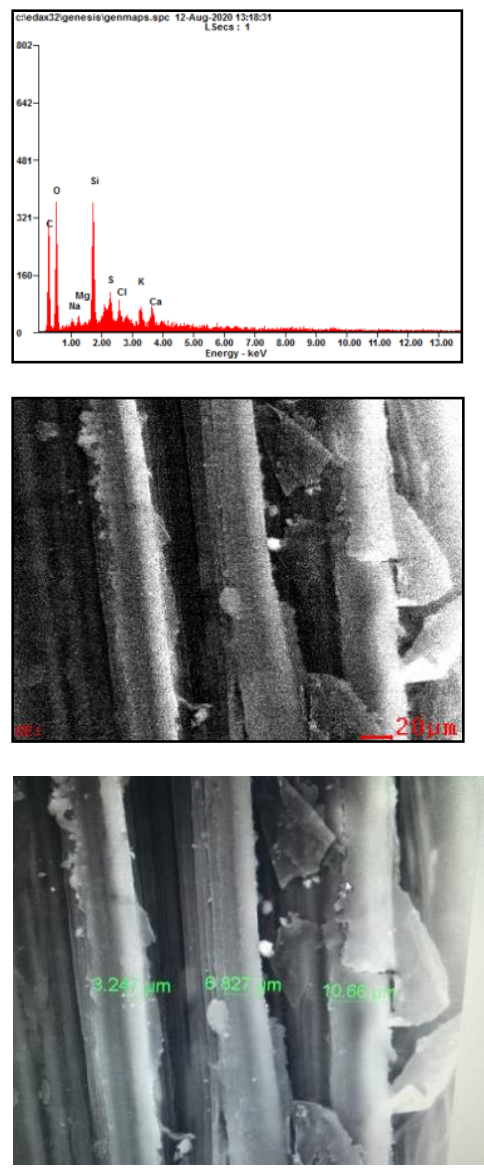

(a)
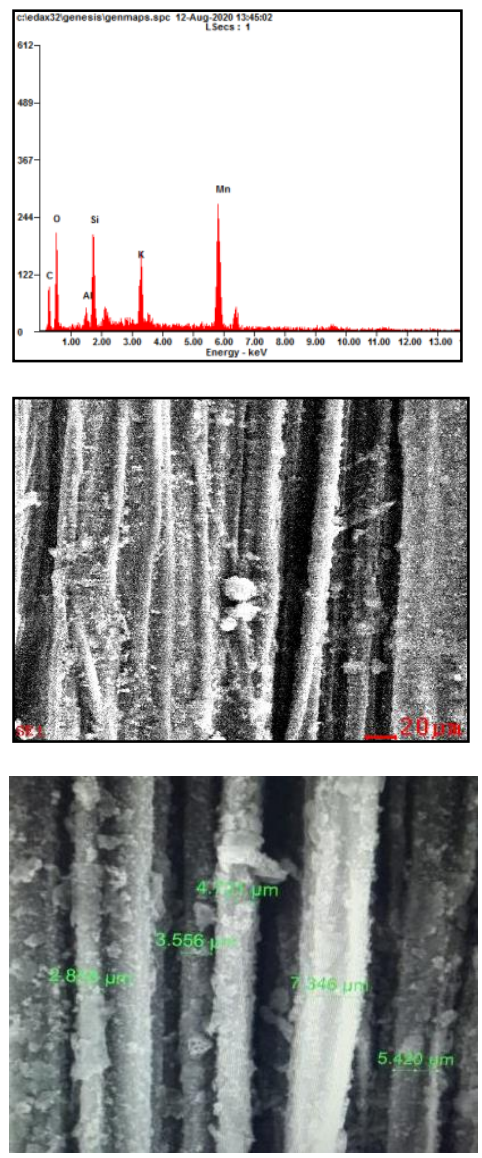

(b)
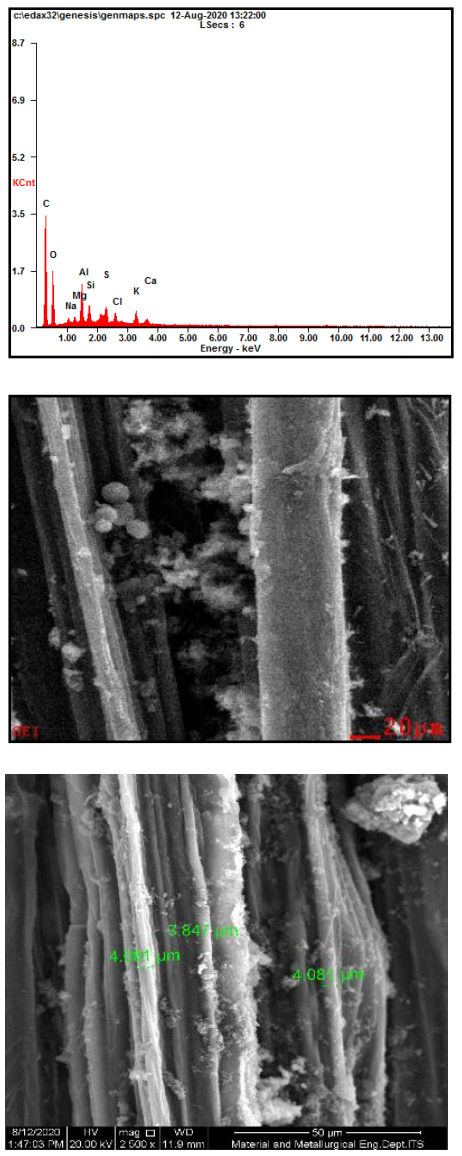

(c)

FIGURE 1. The SEM-EDX results of purun tikus: (a) without treatment, (b) $\mathrm{KMnO}_{4} 2 \%$ treatment, (c) NAOH $5 \%$ treatment.

The elements found in the fiber of purun tikus without treatment are $\mathrm{C}, \mathrm{O}, \mathrm{Na}, \mathrm{Mg}, \mathrm{Si}, \mathrm{S}, \mathrm{Cl}$, $\mathrm{K}, \mathrm{Ca}$, and $\mathrm{Al}$. Meanwhile, the elements' content of purun tikus after treatment with $\mathrm{KMnO}_{4}$ were $\mathrm{C}, \mathrm{O}, \mathrm{Si}, \mathrm{K}, \mathrm{Al}$, and $\mathrm{Mn}$. There is a change in elemental content after being given $\mathrm{KMnO}_{4}$ $2 \%$ treatment; some elements were reduced, such as $\mathrm{C}$ and $\mathrm{O}$, some elements were increased, such as $\mathrm{Si}$ and K, and some no longer detected elements. The same results were also given by 
$\mathrm{NaOH} 5 \%$ treatment. As shown in FIGURE 1, the reduction of element content was much higher than $\mathrm{KMnO}_{4} \%$ treatment. It could be assumed that $\mathrm{NaOH}$ treatment was better than $\mathrm{KMnO}_{4}$ treatment in the case of removing lignin and hemicellulose in purun tikus fiber. This is in line with some research where $\mathrm{KMnO}_{4}$ and $\mathrm{NaOH}$ were removed lignin from the fiber $[11,16,17]$.

Comparing the fiber morphology of purun tikus (in FIGURE 1), the fibers after $\mathrm{KMnO}_{4} 2 \%$ and $\mathrm{NaOH} 5 \%$ treatment were smaller in diameter than before treatment. Lignin is present in the outer layer of cellulose, which binds the structure of plant cells. Therefore the alkaline treatment can be easily released lignin, and the diameter of the fiber after treated experiences shrinkage. It can be seen that the alkaline treatment also makes the purun tikus cleaner because it removes lignin and hemicellulose. The alkaline treatments also seem to make the fiber surface rougher. This surface roughness could benefit when used as a reinforcing composite material because it would increase the adhesion between the fiber and the matrix.

In FIGURE 1, the sample size treated with $\mathrm{KMnO}_{4} 2 \%$ was $2,858-7,346 \mu \mathrm{m}$ and smaller than the sample without treatment, which is $3.247-10.66 \mu \mathrm{m}$. Meanwhile, the diameter of the fiber alkaline $\mathrm{NaOH} 5 \%$ treatment was $3.84-4.99 \mu \mathrm{m}$. So it can be concluded that the delignification treatment reduced the sized fiber of purun tikus.

Several studies regarding the size modification of natural fibers or the cellulose isolation process to improve the mechanical properties of fibers have been carried out; one of them is the research conducted by Lismeri et al., which used cassava stem waste as a source of cellulose [18]. Composites using cellulose fillers $<1000 \mathrm{~nm}$ showed a more homogeneous matrix than using fillers $>1000 \mathrm{~nm}$. The addition of the filler to the composite caused an increase in tensile strength, Young's modulus, and composite density.

The chemical, physical and mechanical characteristics of purun tikus fiber without treatment and immersion treatment with $\mathrm{KMnO}_{4} 2 \%$ and $\mathrm{NaOH} 5 \%$ are shown in TABLE 1. 
TABLE 1. The results of water content, lignin, cellulose, hemicellulose, density, and the tensile strength of purun tikus fiber without treatment, treated with $\mathrm{KMnO}_{4} 2 \%$ and $\mathrm{NaOH} 5 \%$.

\begin{tabular}{|c|c|c|c|c|c|c|c|}
\hline \multirow[b]{2}{*}{ Treatment } & \multirow[b]{2}{*}{ Sample } & \multicolumn{4}{|c|}{ Concentration $(\%)$} & \multirow{2}{*}{$\begin{array}{l}\text { Density } \\
\left(\mathrm{g} / \mathrm{cm}^{3}\right)\end{array}$} & \multirow{2}{*}{$\begin{array}{l}\text { Tensile } \\
\text { strength } \\
\left(\mathrm{kg} / \mathrm{cm}^{2}\right)\end{array}$} \\
\hline & & Water & Lignin & Cellulose & $\begin{array}{l}\text { Hemi } \\
\text { cellulose }\end{array}$ & & \\
\hline \multirow{4}{*}{$\begin{array}{l}\text { Without } \\
\text { treatment }\end{array}$} & 1 & 15.09 & 54.98 & 54.54 & 1.67 & 0.10 & 3.92 \\
\hline & 2 & 14.30 & 42.18 & 54.29 & 3.36 & 0.10 & 3.89 \\
\hline & 3 & 14.93 & 37.93 & 55.40 & 2.47 & 0.10 & 4.17 \\
\hline & Avg & 14.77 & 45.03 & 54.74 & 2.50 & 0.10 & 3.99 \\
\hline \multirow[t]{4}{*}{$\mathrm{KMnO}_{4} 2 \%$} & 1 & 19.23 & 14.29 & 21.16 & 0.80 & 0.20 & 1.86 \\
\hline & 2 & 18.19 & 14.41 & 23.28 & 0.97 & 0.33 & 1.86 \\
\hline & 3 & 17.51 & 18.76 & 23.29 & 0.98 & 0.25 & 2.03 \\
\hline & Avg & 18.31 & 15.82 & 22.58 & 0.92 & 0.26 & 1.92 \\
\hline \multirow{4}{*}{$\mathrm{NaOH} 5 \%$} & 1 & 17.21 & 13.71 & 16.72 & 0.61 & 0.20 & 2.97 \\
\hline & 2 & 18.05 & 13.13 & 22.95 & 0.99 & 0.19 & 2.64 \\
\hline & 3 & 16.06 & 15.05 & 17.62 & 1.29 & 0.19 & 2.86 \\
\hline & Avg & 17.11 & 13.96 & 19.10 & 0.96 & 0.19 & 2.82 \\
\hline
\end{tabular}

Purun tikus plant has high water content because it grows in the swamp. The high water content in the fiber can reduce the composite quality, so it is important to analyze the purun tikus fiber. In TABLE 1 , the average water content of purun tikus without treatment was $14.7734 \%$, and with $\mathrm{KMnO}_{4}, 2 \%$ treatment was $18.3092 \%$, while $\mathrm{NaOH} 5 \%$ treatment was 17.11\%. These results do not meet the SNI 06-3730-1995 standards, where the maximum water content is $15 \%$. In this study, the water content in purun tikus fiber increased when treated with $\mathrm{KMnO}_{4} 2 \%$ and $\mathrm{NaOH} 5 \%$, whereas in other studies, it decreased. Such as the research conducted by Boimau \& Cunha, the moisture content of gewang leaf fiber treated with $\mathrm{NaOH}$ decreased [19]. This is caused by $\mathrm{NaOH}$ reacting with the fiber and releasing hydrogen bonds in the fiber structure network. The increase in water content in the purun tikus fiber after treatment could have occurred because the untreated purun tikus sample was being dried for a long time ( 3 months), so that the water content in the sample was very low so that when immersed in an alkaline solution, the fibers would absorb water. Lignin is a type of organic polymer that an important role in plant structure. The lignin content of each plant has different percentages. Lignin provides inelasticity on the structure of plants. In utilizing natural fibers as a composite material, excess lignin can affect the quality of the composites. Lignin is one of the main components of plant cell walls and a natural phenolic polymer with a high molecular weight, complex composition, and structure. Lignin widely contributes to the growth of plants, the development of tissue/organ, damping resistance, and response to various biotic and abiotic pressure [20].

In TABLE 1, the mean percentage of lignin without treatment was $45.03 \%$, and with $\mathrm{KMnO}_{4}$ $2 \%$, treatment was $15.82 \%$, and $\mathrm{NaOH} 5 \%$ was $13.97 \%$. It can be seen that there was a decrease in lignin levels in the fiber of purun tikus treated in the immersion of $\mathrm{KMnO}_{4} 2 \%$ and $\mathrm{NaOH} \mathrm{5 \%}$. This is in accordance with the objective of alkaline treatment, which is to remove 
lignin from the middle lamellae (the area between lignin-rich plant fibers) to separate the cellulose fibers. Another goal is that the fibers bond easily when mixed with other materials in making composites. $\mathrm{KMnO}_{4} 2 \%$ and $\mathrm{NaOH} 5 \%$ treatments are expected to increase interlocking chemical interfacial adhesion between fibers and matrix. To use the natural fibers as a composite mixture, excess lignin content can reduce the quality obtained $[15,16]$.

The lignin content before being treated was in the high category, which was more than 33\%, but after being immersed in $\mathrm{KMnO}_{4} 2 \%$ and $\mathrm{NaOH} 5 \%$, the lignin level was changed to the low category which is less than $18 \%$ [23]. Research using Borassus fruit fiber treated with $\mathrm{NaOH}$ also showed a reduction in lignin levels [16]. The structure of lignin in plants can be destroyed using an alkaline $\mathrm{NaOH}$ solution. So, using the alkaline treatment on purun tikus can also reduce lignin levels [24].

Cellulose is the main substance found in plant cell walls and helps plants to stay rigid and strong. Cellulose can be used as natural fiber for composite blends. Purun tikus contains cellulose which has the potential to be used as natural fiber. In TABLE 1, it can be seen that the average of the cellulose content obtained without treatment was $54.74 \%$, and with $\mathrm{KMnO}_{4}$ $2 \%$ treatment was $22.58 \%$, and $\mathrm{NaOH} 5 \%$ was $19.10 \%$. The cellulose percentage in purun tikus decreased after being treated with $\mathrm{KMnO}_{4}$ and $\mathrm{NaOH}$. According to Witono [10], alkaline treatment can reduce the composition of plant structures because some are amorphous.

Besides, this happens because the cellulose chain bonds in the amorphous part connected to lignin and hemicellulose are reduced so that the cellulose part is also dissolved in the alkaline treatment. There are partial cellulose chains arranged irregularly in the cellulose structure, resulting in amorphous areas in cellulose. During the initial treatment of alkalis, amorphous hemicellulose and lignin cross-linking with cellulose are dissolved through the destruction of ester linkages [25]. Research using fiber from sugarcane and durian peel with the alkaline treatment of $\mathrm{NaOH}$, the cellulose content obtained the highest cellulose content of $87.37 \%$ at $3.5 \% \mathrm{NaOH}$ concentration with 90 minutes of soaking time [26].

Hemicellulose is part of the plant structure of purun tikus, which acts as a natural matrix. Hemicellulose consists of a collection of polysaccharides with a lower degree of polymerization when compared to cellulose. Hemicellulose is one of a number of heteropolymers (polysaccharide matrix), such as arabinoxylans, and is present in almost all plant cell walls along with cellulose. Hemicellulose is needed in strengthening cell walls through interactions with cellulose and lignin. Extraction of cellulose will reduce hemicellulose levels in purun tikus.

Based on TABLE 1, it is obtained that the hemicellulose analysis of purun tikus without treatment is $2.50 \%$ on average, while with $\mathrm{KMnO}_{4} 2 \%$ treatment is $0.92 \%$ and $\mathrm{NaOH} 5 \%$ is obtained $0.97 \%$. The hemicellulose levels in the fiber of purun tikus decreased after being treated with $\mathrm{KMnO}_{4} 2 \%$ and $\mathrm{NaOH} 5 \%$. These results are compatible with the aim of isolating cellulose from lignin and hemicellulose. The removal of lignin and hemicellulose is usually carried out in the production of cellulose-based materials such as microfiber [27], [28]. 
Natural fibers have a lower density when compared to synthetic fibers, so natural fibers can be used as a lightweight composite material. This could be seen from their density. In TABLE 1 , the average density fiber of purun tikus without treatment was $0.1005 \mathrm{~g} / \mathrm{cm}^{3}$, while with $\mathrm{KMnO}_{4}, 2 \%$ treatment was $0.2617 \mathrm{~g} / \mathrm{cm}^{3}$, and with $\mathrm{NaOH} 5 \%$ treatment, the obtained density was $0.1936 \mathrm{~g} / \mathrm{cm}^{3}$. The density of purun tikus fiber, which was treated with $\mathrm{KMnO}_{4} 2 \%$ and $\mathrm{NaOH}$ were increased. The increase in density in this study is assumed to be due to the untreated purun tikus fiber was too dry and absorbed water when the density test is carried out. Therefore the density of untreated fibers was lower than the fiber's density after treatment. From other studies, the density should be decreased because, by alkaline treatment, the chemical content such as lignin, hemicellulose, and other impurities of the fibers was reduced and created the empty space inside the fibers. It would reduce the density of the fiber. In line with Kencanawati's research using betel nut skin fibers treated with $\mathrm{NaOH}$ showed that the fiber density decreased after being given the alkaline treatment [29].

Mechanical properties can be interpreted as the response or behavior of the material to a given load, and it can be a force, torque, or a combination of both. The mechanical properties of the fiber material can be expressed in several parameters, including tensile strength. Tensile strength is one of the most important basic properties and is often used to characterize a material. The tensile strength is the maximum strength based on the original size.

The tensile strength of purun tikus fiber as written in TABLE 1 was $1,3.99 \mathrm{~kg} / \mathrm{cm}^{2}$ without treatment, while for alkali treatment were 1.92 and $2.82 \mathrm{~kg} / \mathrm{cm}^{2}$ for $\mathrm{KMnO}_{4} 2 \%$ and $\mathrm{NaOH}$ $5 \%$, respectively. Based on the results obtained, it can be seen that the tensile strength fiber of the purun tikus has decreased after being treated with $\mathrm{KMnO}_{4} 2 \%$ and $\mathrm{NaOH} 5 \%$. This happens because lignin, which is useful for strengthening bonds in natural fibers, is removed during the de-lignification process. Although the de-lignification process is intended to facilitate the binding of fibers and matrices to the composite mixing, it affects the tensile strength of the fibers. This is also mentioned by Rambabu et al. that alkali treatment affects the structural behavior of nanocellulose for fiber expansion and shrinkage, agglomeration rate, and interferes with tensile strength [30].

The decrease in tensile strength is due to a reduction in plant structure. The main structure fiber of the purun tikus plant consists of lignin, hemicellulose, and cellulose. Lignin gives plants rigidity and is hydrophobic. Hemicellulose acts as a matrix that binds cellulose. Cellulose is the most important part that is found in almost all plants. Treatment alkaline of $\mathrm{KMnO}_{4}$ and $\mathrm{NaOH}$ reduced lignin and hemicellulose levels in plant structures. This reduction in levels makes the plant structure irregular. Another factor that can affect the results of tensile strength with alkaline treatment is the immersion time used. Natural fibers obtained the highest tensile strength with 5\% alkaline $\mathrm{NaOH}$ treatment and immersion time of 2 hours. A longer immersion time would decrease the tensile strength [10].

Hydrophilic properties are a major problem for all-natural fibers when used as reinforcement in composite materials. The moisture content of the fiber, depending on the non-crystalline part and the voids or vacancies content. The hydrophilic properties of natural fibers affect the overall mechanical properties as well as the physical properties of the fibers. This hydrophilic property should be considered when using purun tikus fiber. 
The amorphous matrix phase in the cell wall is very complex and consists of hemicellulose, lignin. Hemicellulose molecules are hydrogen bound to cellulose and act as binders between cellulose microfibrils, forming cellulose-hemicellulose networks, and are the main structural components of fiber cells. The hydrophobic lignin tissue influences the properties of other tissues acts as a coupling agent and increases the stiffness of the cellulose/hemicellulose composite. The structure, cell size, and chemical composition of the fiber are the most important variables that determine the overall properties of the fiber.

Natural fibers can be processed in various ways to produce reinforcing agents which have different mechanical properties. In small fiber sizes up to nano, cellulose crystals can be developed in the form of composite materials. In this study, the diameter size of the treated purun tikus fiber was smaller than the diameter of the untreated fiber. The diameter of the purun tikus fiber without treatment was $3.247-10.66 \mu \mathrm{m}$. Meanwhile, the size of the fiber with $\mathrm{KMnO}_{4} 2 \%$ treatment was 2,858 - 7,346 $\mu \mathrm{m}$, while $\mathrm{NaOH} 5 \%$ treatment obtained fibers with a size of $3.84-4.99 \mu \mathrm{m}$. So it can be concluded that de-lignification treatment using $\mathrm{NaOH} 5 \%$ and $\mathrm{KMnO}_{4} 2 \%$ reduced the size of the purun tikus fiber.

In general, a smaller fiber diameter would have higher composite strength. Natural fiber materials, especially purun tikus fibers, are candidates as reinforcing materials to produce lightweight composite materials. This could be looked at the density of purun tikus fibers. The

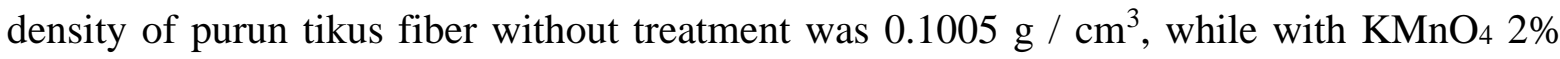
treatment was $0.2617 \mathrm{~g} / \mathrm{cm}^{3}$, and with $5 \% \mathrm{NaOH}$ treatment, it was obtained $0.1936 \mathrm{~g} / \mathrm{cm}^{3}$.

While lignin and cellulose purun tikus fiber with de-lignification treatment using $\mathrm{NaOH} 5 \%$ and $\mathrm{KMnO}_{4} 2 \%$ decreased by $30 \%$ compared to without treatment. It is expected that purun tikus fibers could be used in the manufacture of composites and provide added value economically.

\section{CONCLUSION}

Overall, there was an increase in water content and density as well as a decrease in lignin, cellulose, and hemicellulose levels as well as tensile strength in the fibers of purun tikus treated with $\mathrm{KMnO}_{4} 2 \%$ and $\mathrm{NaOH} 5 \%$. The diameter size of the fiber with the treatment is smaller compared to the fiber without treatment. The fiber size with $\mathrm{KMnO}_{4} 2 \%$ treatment was 2,858 - 7,346 $\mu \mathrm{m}$, while $\mathrm{NaOH} 5 \%$ treatment obtained fibers with a size of $3.84-4.99 \mu \mathrm{m} . \mathrm{NaOH}$ treatment was better than $\mathrm{KMnO}_{4}$ treatment in terms of reducing water content, lignin, cellulose, and density as well as increasing the compressive strength of purun tikus fibers. So it can be concluded that de-lignification treatment can reduce the size fiber of purun tikus and reduce lignin, cellulose, and hemicellulose level, so it is hoped that it will make fibers of purun tikus stronger when used as a composite material and can bind well to the matrix.

\section{ACKNOWLEDGMENT}

Thank you to all those who have helped in this research, especially the Institute for Research and Community Service, the University of Lambung Mangkurat, which has provided funds through the 2020 Research Obligated Lecturer Program. 


\section{REFERENCES}

[1] I. N. P. Nugraha et al., "Analisis perbandingan kekuatan material hasil rekayasa serat alam Agave sisal dan gebang untuk rancangan body kendaraan listrik Ganesha1.0 generasi I," in Seminar Nasional Vokasi dan Teknologi, pp. 329-339, 2016.

[2] B. Wang et al., "Flax fiber-reinforced thermoplastic composites J. Soc. Eng. Agric. Food," Biol. Syst, 2003.

[3] Maryanti et al., "Pengaruh alkalisasi komposit serat kelapa poliester terhadap kekuatan tarik," Rekayasa Mesin, vol. 2, no. 2, pp. 123-129, 2011.

[4] S. Asikin and M. Thamrin, "Manfaat purun tikus (Eleocharis dulcis) pada ekosistem sawah rawa," Litbang Pertan, vol. 31, no. 1, pp. 35-42, 2012.

[5] N. S. Prihatini et al., "Potensi Purun Tikus (Eleocharis dulcis) Sebagai Biofilter Proc. Environ. Talk Towar. A Better Green Living June p. 154-165, 2011.

[6] H. Wardhana and N. H. Haryanti, "The characteristics of purun tikus particle board cement board," IOSR Journal of Appl. Chemistry, vol. 10, no. 1, 2017.

[7] N. H. Haryanti and H. Wardhana, "Purun tikus ( Eleocharis dulcis ) fiber composition as cement board composite material," J. Biodivers. Environ. Sci, vol. 11, no. 3, pp. 137$142,2017$.

[8] N. H. Suryajaya Haryanti, S. Husain and M. Safitri, "Preliminary study of activated carbon from water chestnut ( Eleocharis dulcis )," Journal of Physcs, Conf. Ser, vol. 1572, no. 1, p. 012053, 2020.

[9] H Soemarno A Rachmansyah and Fathurrazie A, 2015 Chemical, Physical, and Mechanical Features of Purun Tikus (Eleocharis dulcis) Fiber Asian Acad. Res. J. Multidiciplinary 2 p. 127-134.

[10] K. Witono et al., "Pengaruh perlakuan alkali $(\mathrm{NaOH})$ terhadap morfologi dan kekuatan tarik serat mendong," Rekayasa Mesin, vol. 4, no. 3, pp. 227-234, 2013.

[11] Kosjoko, A. A. Sonief and D. Sutikno, "Pengaruh waktu perlakuan kalium permanganate (KMnO4) terhadap sifat mekanik komposit serat purun tikus ( Eleocharis dulcis )," Rekayasa Mesin, vol. 2, no. 3, pp. 193-198, 2011.

[12] H. Wardhana and N. H. Haryanti, "Variasi komposisi serat purun tikus (Eleocharis dulcis) dan waktu perendaman $\mathrm{KMnO} 4$ terhadap sifat fisik komposit papan semen," in Seminar Nasional Tahunan VI, pp. 30-38, 2019.

[13] Sulihingtyas, W. Dwijani and I. P. A. S. Mahardika, "Pembuatan dan karakterisasi arang aktif dari batang tanaman gumitir (Tagetes erecta) yang diaktivasi dengan H3PO4 Kimia," vol. 11, no. 1, pp. 1-9, 2017.

[14] Indonesia national standard (SNI) No. 01- 6235 - 2000.

[15] Indonesia National Standar (SNI) No. 0444 -1989.

[16] L. Boopathi, P. S. Sampath and K. Mylsamy, "Investigation of physical, chemical and mechanical properties of raw and alkali treated borassus fruit fiber Compos," Part B 43, vol. 8, pp. 3044-3052, 2012. 
[17] Kosjoko, "Upaya peningkatan kualitas sifat mekanik komposit serat purun tikus (Eleocharis dulcis) bermatriks polyester dengan perlakuan $\mathrm{NaOH}$," in Seminar Nasional Tahunan Teknik Mesin XIV (SNTTM XIV), pp. 1-5, 2015.

[18] L. Lismeri et al., "Aplikasi fiber selulosa dari limbah batang ubi kayu sebagai film komposit berbasis low density polyethylene (LDPE)," in Seminar Nasional Kulit, Karet dan Plastik, vol. 7, pp. 69-82, 2018.

[19] K. Boimau and T. D. Cunha, "Pengaruh panjang serat terhadap sifat bending komposit poliester berpenguat serat daun gewang," in Seminar Nasional Tahunan Teknik Mesin XIV (SNTTM XIV), pp. 1-4, 2015.

[20] Q. Liu, L. Luo and L. Zheng, "Lignins: Biosynthesis and biological functions in plants," International journal of molecular sciences, vol. 19, no. 335, pp. 1-16, 2018.

[21] Andrade-Mahecha et al., "Achira as a source of biodegradable materials: Isolation and characterization of nanofibers," Carbohydr. Polym, vol. 123, pp. 406-415, 2015.

[22] K. Jha et al., "Potential biodegradable matrices and fiber treatment for green composites: A review AIMS Mater. Sci,” vol. 6, no. 1, pp. 119-138, 2019.

[23] H. S. Wibisono, Jasni and W. O. M. Arsyad, "Komposisi kimia dan keawetan alami delapan jenis kayu di bawah naungan," Jurnal Penelitian Hasil hutan, vol. 36, no. 1, pp. 59-65, 2018.

[24] J. P. Reddy and J. W. Rhim, "Extraction and characterization of cellulose microfibers from agricultural wastes of onion and garlic," Journal of Natural Fibers, vol. 15, no. 4 pp. 465-473, 2018.

[25] S. Sun, X. Cao and R. Sun, "The role of pretreatment in improving the enzymatic hydrolysis of lignocellulosic materials," Bioresour Technology, vol. 199, pp. 49-58, 2016.

[26] C. Masyitah and B. Aritonang, "The preparation and characterization of paper from durian rind and bagasse using alkalization separation method," International Journal of Respiratory Medicine, vol. 1, no. 1, pp. 32-38, 2019.

[27] L. H. Saputri and R. Sukmawan, "Pengaruh proses blending dan ultrasonikasi terhadap struktur morfologi ekstrak serat limbah batang kelapa sawit untuk bahan baku bioplastik (selulosa asetat)," Rekayasa, vol. 13, no. 1, pp. 15-21, 2020.

[28] H. Qi, "Nanocellulose-based functional materials SpringerBriefs," in Applied Sciences and Technology, 2017.

[29] C. I. P. K. Kencanawati et al., "Pengaruh perlakukan alkali terhadap sifat fisik dan mekanik serat kulit buah pinang," Jurnal Energi dan Manufaktur, vol. 11, no. 1, pp. 610, 2018.

[30] N. Rambabu et al., "Production of nanocellulose fibers from pinecone biomass: Evaluation and optimization of chemical and mechanical treatment conditions on mechanical properties of nanocellulose films," Ind. Crops Prod, vol. 83, pp. 746-754, 2016. 
